\title{
SMART-COMPLEX OF ELECTRONIC TRAINING RESOURCES
}

\author{
HUMENNYI OLEKSANDR D., Ph.D \\ Senior Researcher of the Electronic Learning Resources Laboratory; Institute of Professional \\ Technical Education of the National Academy of Pedagogical Sciences of Ukraine; city of \\ Kiev; Ukraine \\ https://orcid.org/0000-0001-6596-3551 \\ E-mail: Humennyi@,ivet.edu.ua
}

\begin{abstract}
Annotation. The definition of a Smart-complex of educational discipline and its technology is given. Attention is focused on the form of the Smart-complex and constructive elements: the creative educational environment, the author's environment, the non-verbal environment, the encyclopedia, the creative / self-realization environment, the monitoring / self-evaluation environment.

A feature of the Smart-complex of the academic discipline is the integration into it of the structural equalization block. Constructive alignment (alignment) is based on the design of the student's own learning participation in educational projects. Alignment refers to creating an appropriate learning environment and involves selecting the most appropriate training activities and evaluating each learning outcome. If the result of the training is to develop analytical skills, then for the assessment it is necessary to build questions and scenarios for their development.

Two main components of the structural alignment are considered:

1) the first component is based on cognitive psychology and constructivist theory, recognizes the importance of linking new material with the concepts and experiences of students and extrapolation to possible future scenarios in the process of mission activity they comprehend what they are doing during training;

2) the second component is based on the declaration by the teacher of the correspondence between the planned educational activities and the results of the training of students. This makes planning of educational activities and development of self-assessment criteria for organizing feedback.

It is necessary to take into account the impact of Smart-complexes of educational disciplines on three think-tank training networks: 1) effective networks (why learn) several ways of presenting to give students different ways of obtaining information and knowledge; 2) recognition networks (learning outcomes) - several ways of expressing them to provide them with an alternative for demonstrating what they know; 3) strategic exercises (how to learn) - several ways to increase the motivation for learning to attract their attention to both their own learning project and its technical and historical decision. Smart-complexes of educational disciplines should be: 1) scientific; 2) with user-friendly interface; 3) have a connection with LMS; 4) structured; 5) with visual material; 6) working in Off-line mode; 7) used on various devices in an educational institution, as well as at home.

Keywords: Smart-complex; constructive alignment; creative environment; copyright environment; non-verbal environment; Smart-technology.
\end{abstract}

\section{INTRODUCTION}

Formulation of the problem. Development of the Smart-complex of the discipline for training of competitive qualified specialists.Аналіз останніх досліджень і публікацій.

To date, e-text projects focus on the interface and technical aspects to improve user perception of information. Guidance principles and strategies for electronic textbooks are still widely and systematically evaluated. The study of the design of the electronic textbook is still in its infancy. Pedagogical design needs more attention from the point of view of developing electronic tutorials for more effective learning.

In the last decade, the use of electronic textbooks has attracted the attention of researchers and practitioners. 
Spanovic[1] proposes to implement a systematic approach to the conceptual design of electronic textbooks, which would support optimal individualization, encouraged the study of discoveries based on the student's activities and considered the benefits of using this medium. However, there is no detailed training design and information practice on how these goals can be achieved.

The priority issue was noted in the study Railean[2] the argument that the pedagogy of the e-book is aimed not only at the presentation, but also for the creation of knowledge and the maintenance of interdependence between cognitive, affective and psychomotor goals. The author proposes to structure the design of metasystems with four elements: methodology, motivation, efficiency and evaluation of the context of e-learning. The framework should be consistent with the principles of self-regulation, personalization, clarity, dynamism, flexibility, diversity of reviews and ergonomics.

Similarly, Embong[3] et al. proposed six principles for the development of electronic textbooks. These principles include: various presentations of information and activities, the simplification of the student evaluation scheme, the automation of feedback, the provision of background information for the learning process and the provision of stable knowledge resources.

The growth of practical training strategies included the integration of visual memory cards into the software of the electronic textbook and the provision of reading strategies Li et al[4]. In the methodological perspective, it is proposed to integrate into the textbook a toolkit for teaching staff to set up training facilities, and tools for students to be able to personalize textbook materials to facilitate learning in an integrated learning environment. To improve student learning, it is recommended to reduce the number of annotations to instructors, while increasing the number of multimedia educational videos embedded in electronic tutorials. All these strategies emphasize the distinctive feature of electronic textbooks that support personalized learning.

In addition, Luik, P., \& Mikk, J[5] distinguishes between the use of electronic textbooks for students with different levels of achievement and argue that students with a low level of achievement benefit from the features of electronic textbooks. These features include clear instructions, familiar icons, examples and answers on the keyboard. Students with a higher level of achievement in the study of the discipline have the opportunity to deepen their knowledge at the expense of quality navigational opportunities for the development of creative projects on the Internet. Conclusions indicate that the development of electronic ordering tools should vary depending on the level of achievement of the student.

Doctor of Philosophy Melissa Mullin in his study of the electronic textbook emphasizes the need to build its structure to enable students to cognitive flexibility in their work: "Cognitive flexibility and control is the ability to change what you think about how you think about it, and even about it. what do you think about it, in other words, about the ability to change your mind. Cognitive flexibility is required in various ways throughout the school day .... Cognitive control is the ability to switch thinking, automatically or intentionally, in situations requiring flexibility. "

The purpose of the article. To show the methodological and technological bases of creation of the Smart-complex as a programmable means for students to master the discipline

\section{THEORETICAL BASES OF THE STUDY}

The gap between full-time and distance education is becoming increasingly blurred on the basis of modern electronic, including online, technologies. Depending on the degree to which online technologies are used in the learning process, they distinguish between traditional teaching (without the use of electronic technologies), traditional web-based learning, blended learning, full online learning, more than $80 \%$ of which are held remotely. 
The need for implementing educational programs using e-learning, distance learning technologies is also emphasized in the documents of the Ministry of Education and Science of Ukraine. Thus, in the concept of "National Educational Electronic Platform" it is stated: "A solution is required that will meet three criteria: - guarantees access to quality free e-textbooks and other electronic educational resources for secondary school students; - allows the development of national production of electronic educational resources; - while flexible enough to respond to ever-changing environments, to implement rapidly developing technologies. " disciplines.

Such requirements, in our opinion, correspond to Smart-complexes of educational

Smart-complex of educational discipline is a complex informational structured set 1 system of electronic educational resource of the informational and educational environment of educational-methodical appointment for the provision of a continuous, complete didactic cycle of the learning process, which consists of organizational materials for classroom and independent work of students in the framework of their mastering of discipline. according to the curriculum and systematized theoretical, practical, controlling materials built on the principles of interactivity and adaptability, openness and information dystantsiynosti.

Smart complexes of educational disciplines need to be built taking into account the impact on the three brain education networks identified by the researchers at the Center for Applied Special Educational Technologies, CAST, in partnership with Stanford University teachers (Figure 1): 1) effective networks (why learn) - several ways of presenting, to give students different ways of obtaining information and knowledge; 2) recognition network (learning outcomes) - several ways of expressing to give them an alternative to demonstrating what they know; 3) Strategic Learning (how to study) - There are several ways to motivate learning to attract their attention to both their own learning project and its techno-historical decision.

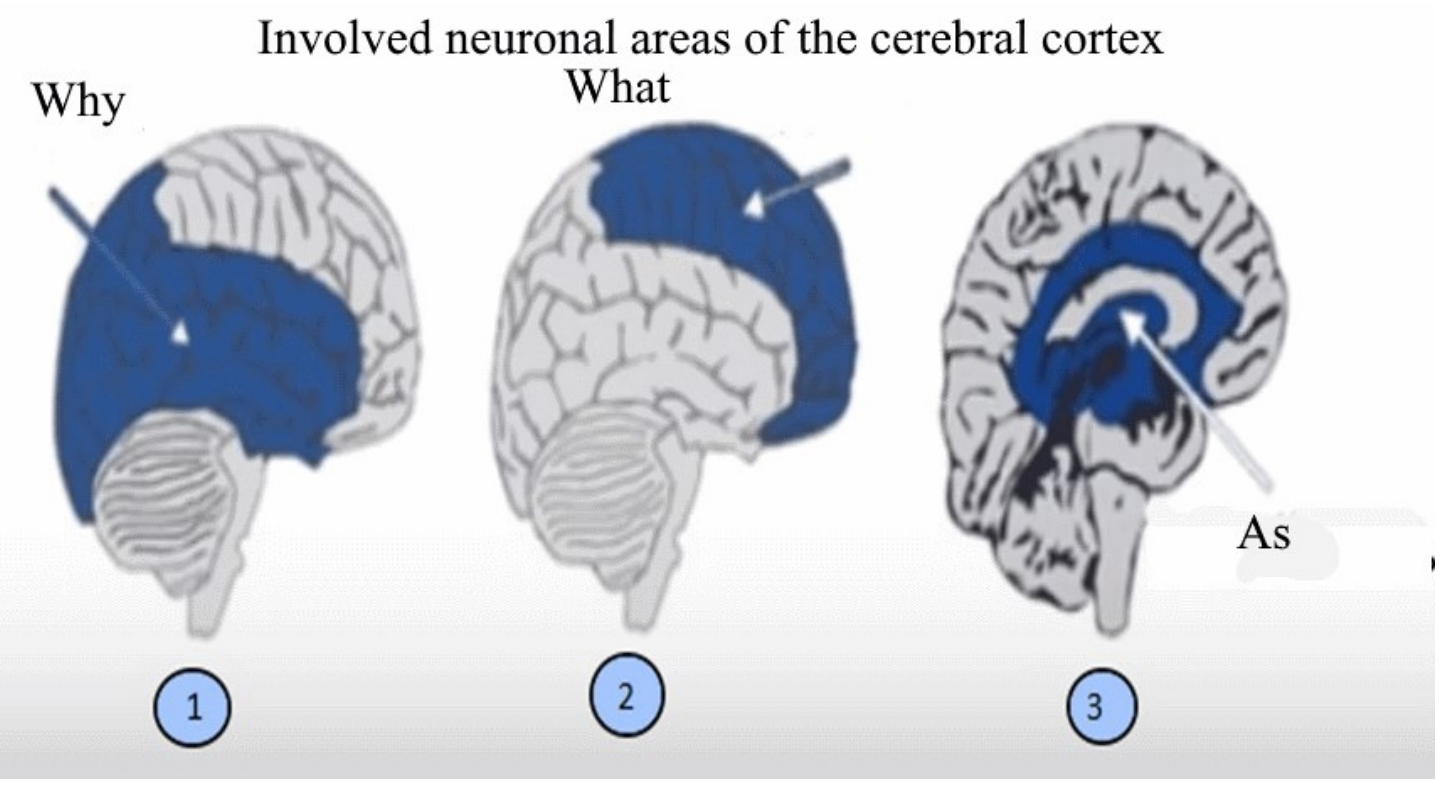

Fig.1 Three brain training networks for Smart-complexes[6]

Neural networks of our brain continuously react to all possible signals of sensory organs and many hours use of the computer puts the human brain in constant digital stimulation. A research team from the University of California at Los Angeles (UCLA) has hypothesized that online searches and other leisure activities on the Web quickly cause changes in the nervous system and the devices can fix them. To test the hypothesis, a 
magnetic resonance imaging was used in the process of finding reliable information on Google. The figure (Figure 2) shows two arrows showing the neural network that searches for the brain to search on Google.

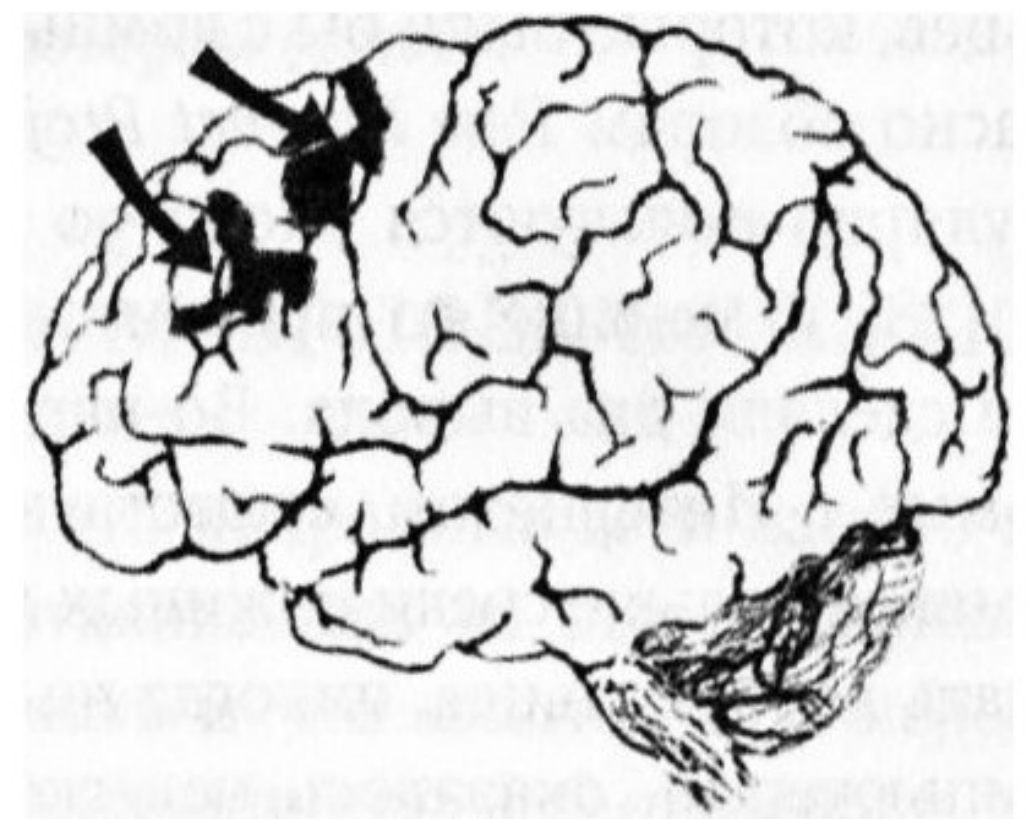

Fig.2 Areas of influence of the Internet search on the neural regions of the brain

Smart-complexes of educational disciplines should be: 1) scientific; 2) with a friendly interface; 3) have connection with LMS; 4) structured; 5) with visual material; 6) working in off-line mode; 7) used on different devices both at the educational institution and at home.

The form of the Smart-complex is modular with a fuzzy limit, and the structure is composite and is constructed on the invariant part and the structural alignment block.

The constructive elements of the Smart-complex are: creative educational environment, author's environment, nonverbal environment, encyclopedia, environment of creativity / self-realization, environment of control / self-evaluation.

Creative educational environment. The content of education becomes varied and develops during the student's educational activity. He becomes the subject, the designer of his professional training; a full source and organizer of his knowledge: develops a plan of occupations, defines a personal position on the key issues of developing a project in teaching activities. The creative educational environment is connected with the control environment / self-evaluation. In the area of "overlaying" the constructivist understanding of the nature of learning and the agreed design for learning based on projected results, according to which all components of the curriculum are directed to maximize the impact on student learning. For example, assessment tools and training strategies are consistent with learning outcomesКонструктивне вирівнювання (узгодження) засноване на конструюванні студентом свого навчання участю у відповідних навчальних проектах (звідси конструктивний). Вирівнювання відноситься до створення відповідного навчального середовища і передбачає вибір найбільш відповідних навчальних заходів та оцінювання кожного результату навчання. Якщо результат, навчання полягає в тому, щоб розвивати analytical skills and skills, and for evaluation it is necessary to build questions and scenarios for their development.

Consider two main components of constructive alignment:

1) The first component is based on cognitive psychology and constructivist theory, recognizes the importance of linking new material with the concepts and experiences of 
students and extrapolation to possible future scenarios in the process of thinking activity they understand what they are doing during their studies;

2) the second component is based on the declaration of the correspondent between the planned learning outcomes and student learning outcomes. This enables planning of training activities and the development of self-assessment criteria for feedback organization.

Constructive alignment is aimed at students. The role of the teacher is to create an appropriate learning environment in which a flexible approach to the development and implementation of curricula is implemented, which offers students complete and equal learning opportunities.

Author's environment. The peculiarities of the educational institution, the specialty of the specialty, the student, the inclusion of additional materials in the electronic encyclopedia, the replenishing of the medium of creativity, the development of teaching materials, etc. are taken into account.

Nonverbal environment. The methodical reception of the virtual presence of a pedagogical worker is implemented:

- curator of the online platform (reproductive tasks based on the principle of "do me," online counseling, etc.);

- Internet surfing instructor (tasks for forming critical and logical thinking; development of media literacy; network security; use of trusted Internet resources).

\section{Encyclopedia.}

The medium of creativity / self-realization, developed by the model of the Kosko neural network, based on two ideas: the theory of adaptive resonance of Stefan Grosberg and Hopfield's autosocial memory. The vector of input signals arrives on one set of neurons, and the corresponding output vector is made on another set of neurons. Using the model allows students to generalize, producing the correct reactions, despite the distorted inputs. Additionally, adaptive versions can be implemented, which isolate the reference image from noisy examples. These possibilities strongly resemble the process of human thinking and allow artificial neural networks to make a step in the direction of brain modeling (Fig. 3).

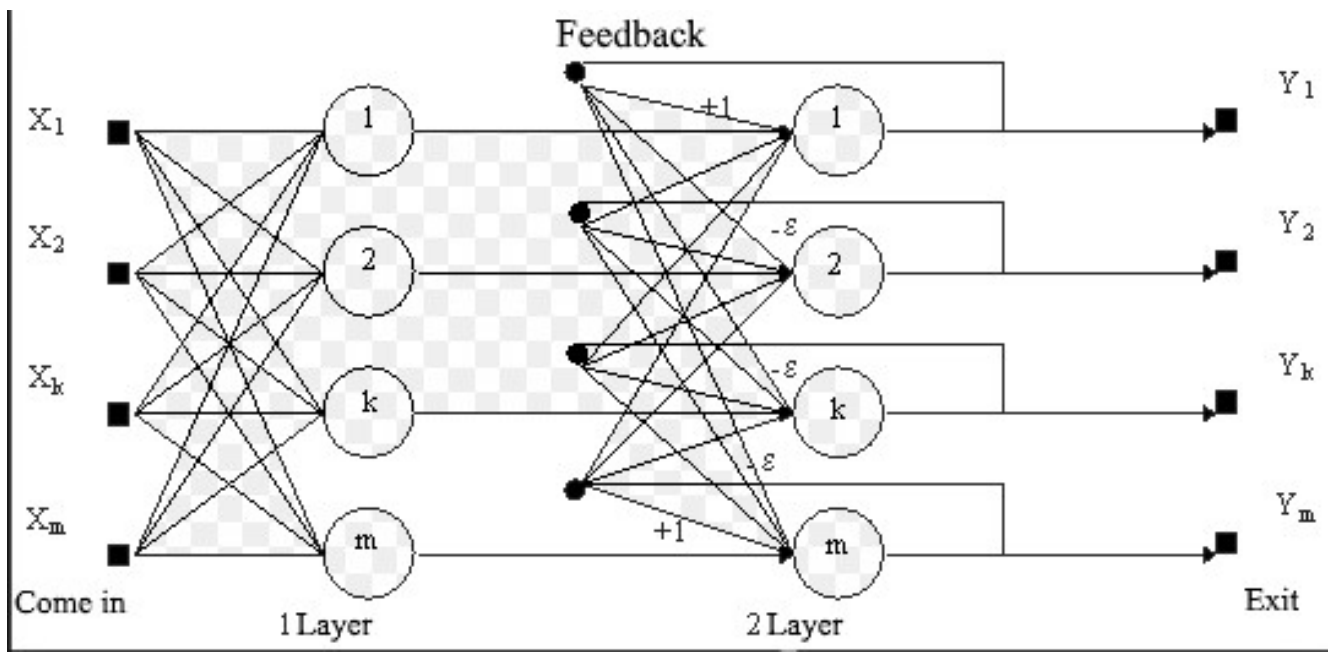

Fig. 3 Using the model of the Kosko neural network

An example of a medium of creativity / self-realization is the use of a "mirror of the rear view", which involves the development of creative potential of students, the formation of a creative person. (Fig. 4). Cognition of the real world is always creativity. Any discovery requires creativity. And even the use of various techniques that facilitate the path to opening 
is a creative process. Various aspects of the problem of creativity were considered by V. Bekhterev, V. Vernadsky, A. Maslou, Y. Ponomarev, A. Poincare, S. Rubinstein, S. Shatskii, and others like that. V. Moljako, revealing the essence of creativity from the standpoint of psychology, notes that creativity is understood as the process of creating something new for this subject. According to O. Leontiev, creative activity can appear both at the level of the operational components of productive or cognitive (educational) activity, and at the level of adjustment of the orientation basis and, finally, the image of the world (scientific creativity). And the novelty here is not in an objectively new end product, but in the independent creation of a system of attitude to the world through personal activity.

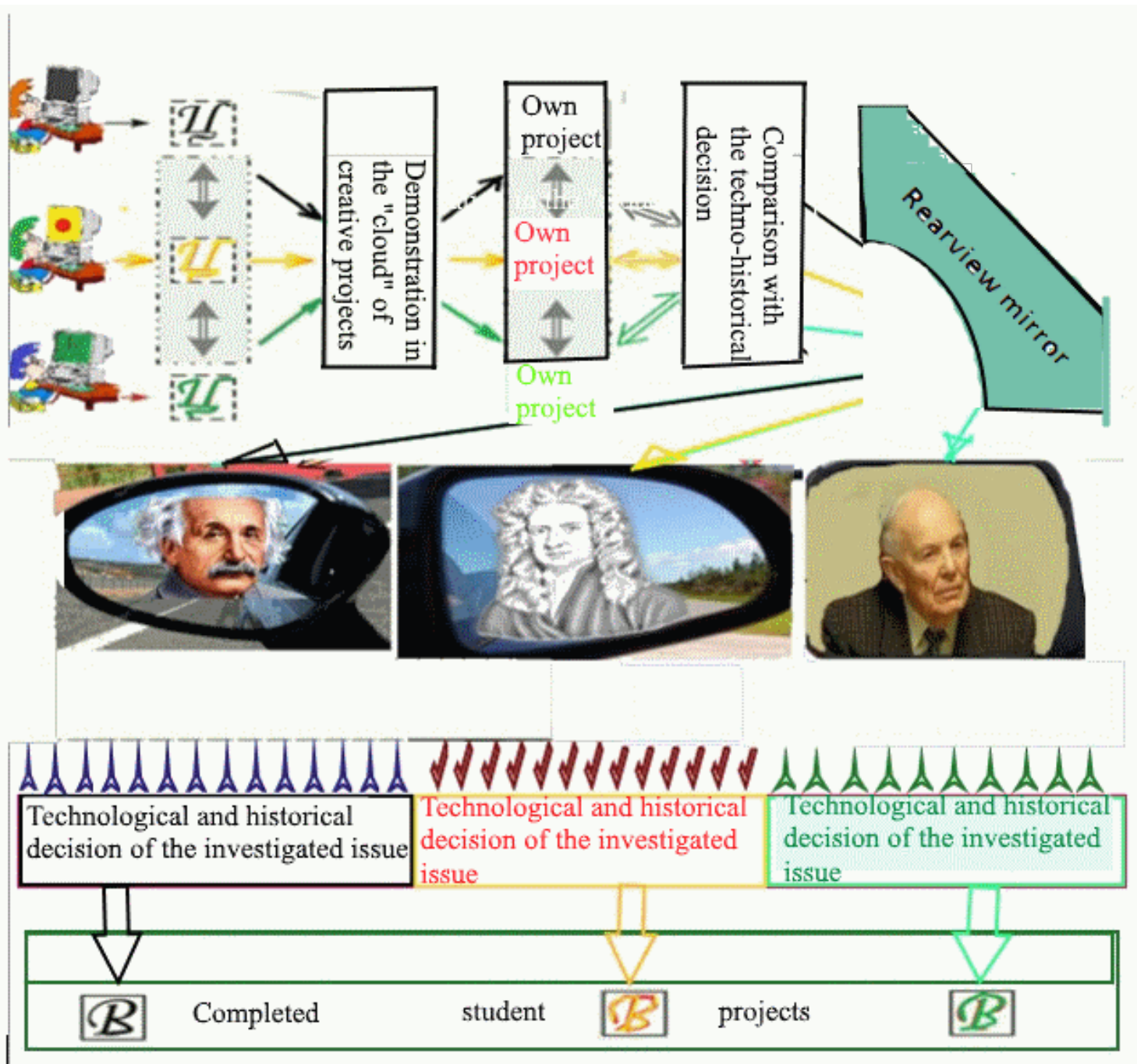

Figure 4. Using the "Rear View Mirror" principle in the Smart-complex of academic disciplines

Environment control / self-assessment. This is a set of prerequisites in which control / selfassessment is carried out (Fig.5). 


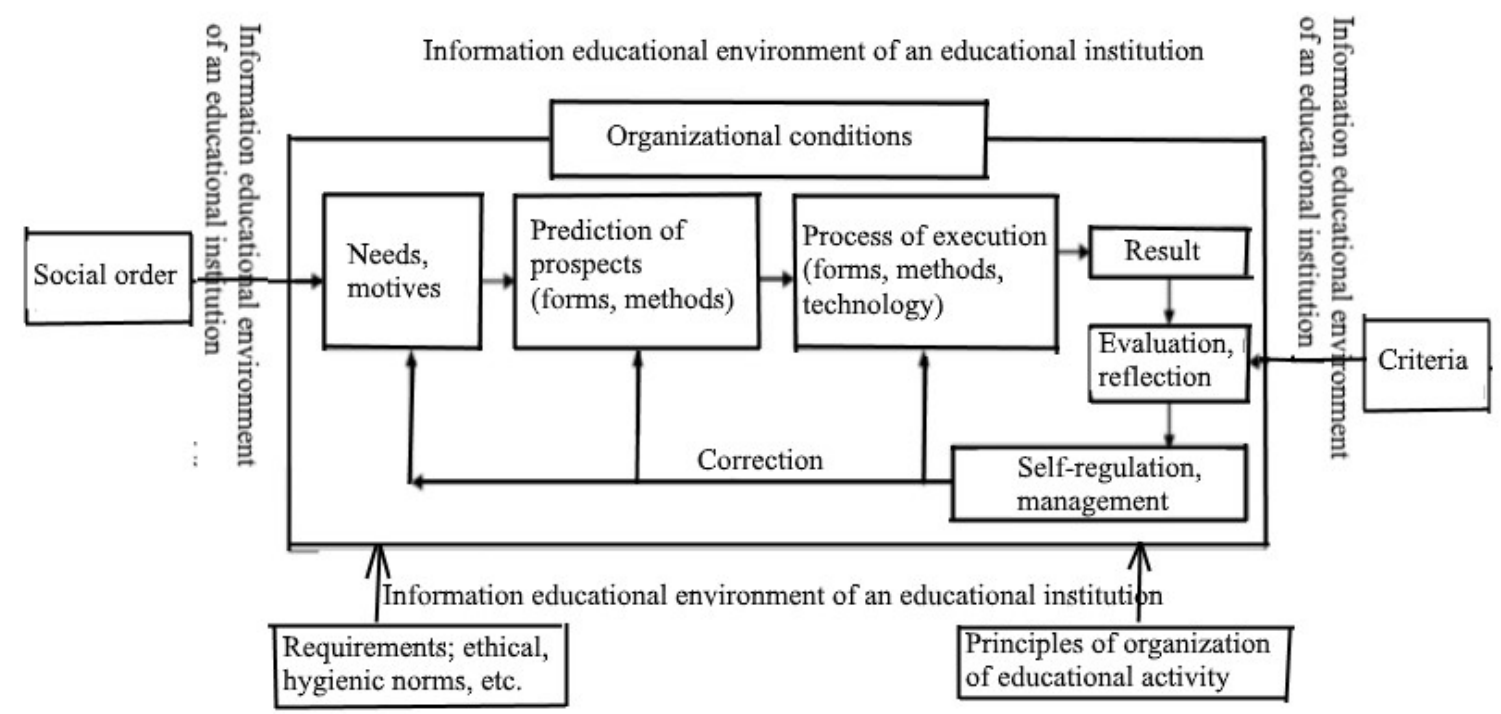

Fig. 5 Organization of control / self-control in the educational and informational environment of an educational institution

Of course, speaking of Smart-complexes, the main focus is on technology. Digital technologies, the development of which resembles an explosion, not only change our way of life and give new ways of communication, but also redraw the work of our brain. Daily use of high-tech - computers, smartphones, video games, Internet searches - makes changes to the work of nerve cells: "thrown" neurotransmitters and new networks are created (while the old ones are gradually collapsing), forcing the brain to evolve at an unprecedented tempo.

In Smart-complexes of technology, they acquire individually-oriented forms and aim at creating new knowledge. The teaching process is based on the movement of knowledge objects from the student to the teacher, in the opposite direction, as well as from the student to the student. In the course of the student's review of the information received on the high-tech screen, the light from the page passes through the lens of the eye, activates the chemical and electrical processes in the retina; the optical nerve signal is transmitted by moleculesneurotransmitters, transmitted to other neurons by a complex network of axons and dendrites in the mind the image of the image on the screen is formed. In the process of creating an elearning course, it is important not to allow the implementation of multitasking tasks.

Multitasking creates conditions for continuous self-promotion and postponement of long-term tasks. If several tasks require a student's attention at the same time, he will perceive the new knowledge superficially - instead of focusing on it. Chronic and intense multitasking can also slow down the systematic development of the frontal cortex (Fig. 6) - the area of the brain, which allows you to see the whole details, postpone encouragement for the future, think abstractly and plan ahead.

If a student always knows how to immediately reward himself and is able to do so for example, playing a computer game or emailing E-Mail, Messenger, etc. - then he will not learn to sacrifice his whims for a tedious project or a boring task that guarantees satisfaction. only in perspective. 


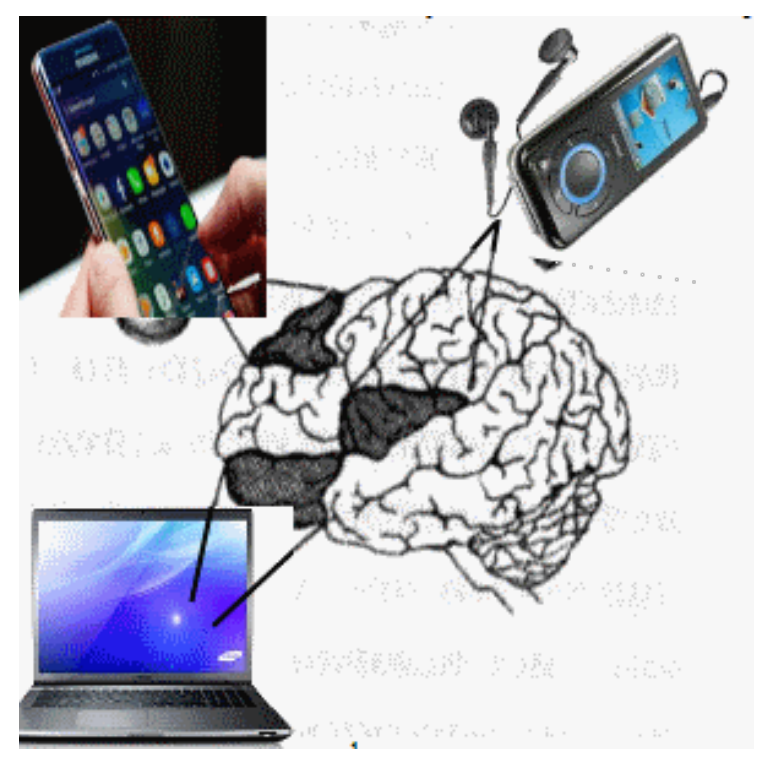

Fig. 6. Multitasking and inhibition of the development of the frontal cortex of the brain

Smart-technology is an educational and ethical practice to promote learning and increase its productivity through the creation, use and management of information and knowledge resources, built on interaction and the exchange of experience among participants in the educational process.

Such a process, organized on the use of innovations and the Internet, provides the opportunity to master professional competences on the basis of systematic multidimensional vision and study of disciplines, taking into account their multidimensional and continuous updating.

In educational technologies, the main aspect was previously directed to the teaching practice of promoting learning, and ethical practice was leveled out. we came to the conclusion that it is necessary to involve appropriate comprehensive means of forming the ethical consciousness and ethical culture of student youth at the stage of training in professional (vocational) educational institutions. After all, the awareness of ethical problems involves high-quality education in general. It is based on the appropriate effective content, as well as interactive methods for engaging students in learning.

Effective formation of the same ethical consciousness repeats the natural processes in which students exhibit ethical-oriented behavior. These processes include simulation, observation and social contacts. Responsible and valuable attitudes towards the world are absorbed more effectively when students have the opportunity to observe, understand and actively use their knowledge. Researchers say: Under conditions where young people have the ability to practice skills in a safe environment, it is likely that they will be ready to use the same skills outside the institution[7].

he student's ethical consciousness represents the main regulation of his actions, which are fixed in the habits, traditions, principles of life and educational activity, mental states, actions, actions and qualities, and provides for the choice of conscious ethical behavior.

Ethical-oriented student behavior is manifested in social interaction between classmates and other participants in the educational process. L. S. Vygotsky[8] noted that social interaction and active participation of the individual in solving problems with peers and adults constitute the basis for the development of thinking.

In Smart-technology a significant place is given to the introduction of heuristic approaches in the process of empirical studies. Empirical learning, learning through 
experience - is a process of obtaining information or acquiring skills through direct, independent study of an object or task execution. The essence of learning through experience - to try to do the job yourself, by the method of "trial and error". And the method of choosing a goal or a direction in solving a task whose correctness is unknown at every step or can not be confirmed is called heuristic. For heuristic approaches during empirical studies it is expedient to use a genetic algorithm or a neural network with the processing of purely empirical information that is not subject to strict rationalization.

\section{RESULTS OF THE STUDY}

Analysis of the results of the experiment conducted by A. D. Korol[9] at the Eidos Distance Learning Center, showed that the heuristic tasks that comprise the component of internal and external dialogue make for the first time students a primary problem and complexity. However, then, the second time, during the "decoding" of this integrity there is a sharp increase in the degree of emotionality and creativity. Dialogue teaches to give an emotional and valuable color to events, to consider from a few points of view the problem, to discuss with thinkers of the past, the present (fig. 1) and forms the preconditions for strengthening the interaction of internal and external dialogues of students for their creative self-realization and integration of educational subjects in the Smart-complex (Table 1).

Table 1

Distribution of pedagogical workers according to estimates of promotion of introduction of heuristic approaches for expanding the information base of the lesson and increasing the availability of educational information,

Quantity, (\%)

\begin{tabular}{|l|c|c|}
\hline \multirow{2}{*}{ Signs } & \multicolumn{2}{|c|}{$\begin{array}{c}\text { In your opinion, the introduction of heuristic approaches } \\
\text { comes: }\end{array}$} \\
\cline { 2 - 3 } & $\begin{array}{c}\text { expanding the information base } \\
\text { of the lesson }\end{array}$ & $\begin{array}{c}\text { increasing the availability of } \\
\text { educational information }\end{array}$ \\
\hline Age & $32,(40)$ & $48,(60)$ \\
\hline up to 30 years old & $54,(42,2)$ & $74,(57,8)$ \\
\hline $\begin{array}{l}\text { 41-50 years old } \\
\text { 41-5ears }\end{array}$ & $46,(45)$ & $56,(55)$ \\
\hline older than 50 years & $51,(38,3)$ & $82,(61,7)$ \\
\hline $\begin{array}{l}\text { Type of subjects to be } \\
\text { taught }\end{array}$ & $53,(46,1)$ & $62,(53,9)$ \\
\hline $\begin{array}{l}\text { natural and } \\
\text { mathematical }\end{array}$ & $49,(42,6)$ & $66,(67,4)$ \\
\hline
\end{tabular}




\begin{tabular}{|l|c|c|}
\hline \multirow{2}{*}{ Signs } & \multicolumn{2}{|c|}{$\begin{array}{c}\text { In your opinion, the introduction of heuristic approaches } \\
\text { comes: }\end{array}$} \\
\cline { 2 - 3 } & $\begin{array}{c}\text { expanding the information base } \\
\text { of the lesson }\end{array}$ & $\begin{array}{c}\text { increasing the availability of } \\
\text { educational information }\end{array}$ \\
\hline general professional & $36,(42,8)$ & $48,(57,2)$ \\
\hline social and humanitarian & $57,(44,5) \%$ & $71,(55,5)$ \\
\hline special discipline & $64,(46,7)$ & $73,(53,3)$ \\
\hline $\begin{array}{l}\text { Experience of } \\
\text { pedagogical activity } \\
0-3 \text { years }\end{array}$ & $41,(35,6)$ & $74,(64,4)$ \\
\hline $4-10$ years old & $58,(46,8)$ & $66,(53,2)$ \\
\hline $11-20$ years old & $32,(48,5)$ & $34,(51,5)$ \\
\hline
\end{tabular}

The next component of Smart-technology - taking into account the experience of groupmates (the "mirror rear view" method). The argument for this is the statement by the Canadian philosopher, philologist, literary critic of the twentieth century Herbert Marshall McLuhan (1911-1980): "We are looking at the present through the rear view mirror. We are going to the future." Learning through experience is very similar to action learning and collaborative learning, but there are differences as well. It is learning through experience that takes place without the direct involvement of the teacher, but requires reflection from his side, that is, participation in the training of the coach is necessary, which will help analyze the experience gained. This method of training gives positive results if it is correctly constructed, otherwise the effect of a water drop on a heated surface will work. (The liquid is separated from the heating surface by a pair of pairs, through which the transfer of heat from the heating surface to the liquid is difficult and water evaporates more slowly). interaction and exchange of experience between the participants in the educational process (Table 2). 
Табличя 2

Distribution of pedagogical workers regarding the use of the model of the Kosko neural network in the educational process

Quantity, (\%)

\begin{tabular}{|c|c|c|}
\hline \multirow{2}{*}{ Signs } & \multicolumn{2}{|c|}{$\begin{array}{l}\text { Do you use the model of the Kosko neural network in } \\
\text { the learning process }\end{array}$} \\
\hline & no & yes \\
\hline $\begin{array}{l}\text { Age } \\
\text { - up to } 30 \text { years }\end{array}$ & $15,(18,8)$ & $65,(81,2)$ \\
\hline $30-40$ years & $17,(13,6)$ & $108,(86,4)$ \\
\hline $41-50$ years & $28,(26,2)$ & $78,(73,8)$ \\
\hline over 50 years old & $27,(20,5)$ & $105,(79,5)$ \\
\hline $\begin{array}{l}\text { Type of subjects to be taught } \\
\text { - natural sciences and mathematics }\end{array}$ & $11,(17,4)$ & $51,(82,6)$ \\
\hline general professional & $13,(24,9)$ & $38,(75,1)$ \\
\hline social and humanitarian & $7,(12,2)$ & $49,(87,8)$ \\
\hline special disciplines & $30,(24,3)$ & $93,(75,7)$ \\
\hline $\begin{array}{l}\text { Experience of pedagogical activity } \\
0-3 \text { years }\end{array}$ & $17,(13,3)$ & $108,(86,7)$ \\
\hline $4-10$ years & $25,(21,9)$ & $90,(78,1)$ \\
\hline $11-20$ years & $31,(22,7)$ & $106,(77,3)$ \\
\hline more than 20 years & $10,(15,8)$ & $56,(84,2)$ \\
\hline
\end{tabular}

In the development of Smart Technology, it is important to adhere to the reduction of the information overload, which enables the user to choose which information is at the center of his attention, and which is a peripheral, which creates conditions for moving the unnecessary information to the interface, thereby providing more information ready for selection. when necessary (aspect of "quiet technology"). Technical devices that are becoming more sophisticated and multifunctional contribute to accelerating the pace of educational activity, require constant attention to be always "in the area of access" to solve several tasks simultaneously. 
In the Oxford English Dictionary, the term "multitasking" in relation to humans is given an interpretation: "The ability of a person to perform several tasks simultaneously»[10].

More and more researchers are saying that the simultaneous implementation of several cases reduces productivity. It turns out that we could do much more if at a certain time focused on just one thing.

The human brain has a lot of information processing capabilities. In the course of performing several cases simultaneously, the brain is constantly switched from one to the other, and does not perceive them synchronously - it successfully implements the distribution of such ability among various tasks, but to perform quality is possible only one specific task[11].

In the study on the use of the model of the neural network of Kosko in the student's learning process, various types of pedagogical workers who differed by age, experience in teaching activities and the type of subjects they teach, participated in the study, which can also confirm the representativeness of the sample of the study.

Table 3

Distribution of pedagogical workers by estimations of decrease of productivity of educational activity of students in introduction of multitasking

Quantity, (\%)

\begin{tabular}{|l|c|c|}
\hline \multirow{2}{*}{ Signs } & \multicolumn{2}{|c|}{$\begin{array}{c}\text { Do you think that learning using information and communication } \\
\text { technologies (ICTs) is more effective than traditional education }\end{array}$} \\
\cline { 2 - 3 } & No & Yes \\
\hline Age & $18,(22,5)$ & $62,(77,5)$ \\
\hline up to 30 years old & $26,(21,0)$ & $99,(79,0)$ \\
\hline $30-40$ years old & $29,(27,6)$ & $77,(72,4)$ \\
\hline 41-50 years & $37,(28,3)$ & $95,(71,7)$ \\
\hline older than 50 years & $15,(23,9)$ & $47,(76,1)$ \\
\hline $\begin{array}{l}\text { Type of subjects to } \\
\text { be taught }\end{array}$ & $14,(27,4)$ & $37,(72,6)$ \\
\hline $\begin{array}{l}\text { natural and } \\
\text { mathematical }\end{array}$ & $27,(23,2)$ & $98,(76,8)$ \\
\hline general professional & $32,(25,4)$ & $108,(77,2)$ \\
\hline $\begin{array}{l}\text { social and } \\
\text { humanitarian }\end{array}$ & $12,(21,0)$ & $93,(74,6)$ \\
\hline special discipline & & \\
\hline
\end{tabular}




\begin{tabular}{|c|c|c|}
\hline \multirow{2}{*}{ Signs } & \multicolumn{2}{|c|}{$\begin{array}{c}\text { Do you think that learning using information and communication } \\
\text { technologies (ICTs) is more effective than traditional education }\end{array}$} \\
\cline { 2 - 3 } & No & Yes \\
\hline $11-20$ років & $32,(23,1)$ & $105,(76,9)$ \\
\hline $\begin{array}{l}\text { more than } 20 \\
\text { years }\end{array}$ & $16,(24,9)$ & $50,(75,1)$ \\
\hline
\end{tabular}

Management of the learning process using the Smart-complex involves the control, that is, the system of checking the effectiveness of its functioning, which is intended to provide external feedback (teacher control) and internal (self-control student). The control is aimed at obtaining information, analyzing what the teacher makes the necessary adjustments to the course of this process. This may be related to changes in the content, the review of the approach to the choice of forms and methods of teaching activity or the fundamental rearrangement of the whole system of work involving the component of the Smart-complex a block of constructive alignment (Table 4).

Table 4

Distribution of pedagogical workers by estimations of assistance in the effectiveness of their activities in the organization of control / self-control of the structural adjustment unit,

Quantity, (\%)

\begin{tabular}{|l|c|c|}
\hline \multirow{2}{*}{ Signs } & \multicolumn{2}{|c|}{$\begin{array}{c}\text { Do you think that the organization of control / self-control of the } \\
\text { structural alignment unit contributes to the effectiveness of learning? }\end{array}$} \\
\cline { 2 - 3 } $\begin{array}{l}\text { up to } 30 \text { years old } \\
\text { Age }\end{array}$ & $11,(14,4)$ & Yes \\
\hline $30-40$ years old & $15,(12,2)$ & $69,(85,6)$ \\
\hline $41-50$ years & $23,(21,7)$ & $110,(87,8)$ \\
\hline & $31,(13,4)$ & $83,(78,3)$ \\
older than 50 years & $4,(7,2)$ & $101,(76,6)$ \\
\hline $\begin{array}{l}\text { Type of subjects to be } \\
\text { taught }\end{array}$ & $5,(4,8)$ & $6,(51,2)$ \\
\hline $\begin{array}{l}\text { natural and } \\
\text { mathematical }\end{array}$ & & $58,(92,8)$ \\
\hline
\end{tabular}




\begin{tabular}{|l|c|c|}
\hline \multirow{2}{*}{\multicolumn{1}{|c|}{ Signs }} & \multicolumn{2}{|c|}{$\begin{array}{c}\text { Do you think that the organization of control / self-control of the } \\
\text { structural alignment unit contributes to the effectiveness of learning? }\end{array}$} \\
\cline { 2 - 3 } & No & Yes \\
\hline general professional & $9,(7,8)$ & $42,(83,4)$ \\
\hline special discipline & $15,(11,9)$ & $108,(88,1)$ \\
\hline $\begin{array}{l}\text { Experience of } \\
\text { pedagogical activity } \\
\mathbf{0 - 3} \text { years }\end{array}$ & $20,(15,8)$ & $105,(84,2)$ \\
\hline $\begin{array}{l}\text { 4-10 years old } \\
\text { (11-20 years old }\end{array}$ & $8,(12,8)$ & $58,(87,2)$ \\
\hline
\end{tabular}

\section{CONCLUSIONS AND PERSPECTIVES FOR FURTHER STUDIES}

1. The article describes methodological and technological bases for the creation of the Smartcomplex as a programmable means of mastering students in the discipline. After all, the employer needs a competent graduate who is capable and ready for a successful professional activity without additional training, without spending time on retraining in the workplace, that is, a professional in his case. We need a creative person with a civic position and professional values, which has a high level of information culture, which has mastered the culture of social and professional life, ready for professional self-actualization. And the use of Smartcomplexes of educational disciplines enables the development of creative personality and creates the preconditions for the formation of a competent graduate - the subject of professional activity - a genuine professional.

2. Characterized by the Smart-complex of the discipline - the form, structure and constructive elements. Particular attention is paid to the disclosure of Smart-technology. The calculations of the obtained results make it possible to establish the fact that pedagogical workers are motivated to develop and develop a Smart-complex of educational disciplines.

\section{REFERENCES}

[1] Spanovic, S. (2010). Pedagogical aspects of e-textbooks. Odgojne Znanosti-Educational Sciences, 12(2), 459-470.

[2] Railean, E. (2012). Trends, issues and solutions in e-Book pedagogy. In T.-T. Goh (Ed.), E-Books and E-Readers for E-Learning (pp. 154-195). Wellington: Victoria Business School, Victoria University of Wellington.

[3] Embong, A. M., Noor, A. M., Ali, R. M. M., Bakar, Z. A., \& Amin, A. R. M. (2012). Teachers' perceptions on the use of e-books as textbooks in the classroom. In Proceedings of World Academy of Science, Engineering and Technology.

[4] Li, L. Y., Chen, G. D., \& Yang, S. J. (2013). Construction of cognitive maps to improve e-book reading and navigation. Computers \& Education, 60(1), 32-39.

[5] Luik, P., \& Mikk, J. (2008). What is important in electronic textbooks for students of different achievement levels? Computers \& Education, 50(4), 1483-1494. 
[6] http://www.cast.org/our-work/about-udl.html\#.WzmqB kzYdU

[7] Victoria Turban, Formation of Ethical Values in Juvenile and Early Maturity [Text] / Turban Victoria. - Electronic format, access mode:http://ib.iitta.gov.ua/5394/1/17.pdf. Title from the screen.

[8] Vygotsky L. S. Psychology / L. S. Vygotsky. - M .: April-Press; Exmo-Press, 2000. - 1007 pp.

[9] A. D. Korol. Analysis of the influence of the dialogue component of heuristic tasks on the level of creative self-realization of participants of distance courses and olympiads [Electronic resource] / Korol A. D. Access mode:http://eidos.ru/journal/2006/0723-2.htm?oprd=1. Title from the screen. Date of application: 11/06/2018.

[10] Multitask // English Oxford Living Dictionares [Електронний ресурс]. - Режим доступу: https://ranslate.google.com.ua/translate?hl=ru\&sl=en\&u=https://en.oxforddictionaries.com/definit ion/multitask\&prev=search

[11] Small, G., Vorgan, G. Brain online. Man in the era of the Internet [Text]. - M .: Azbuka-Atticus, 2011. $352 \mathrm{c}$.

\section{REFERENCE INFORMATION REFERENCE}

Laboratory of Electronic Educational Resources, Institute of Professional Technical Education, National Academy of Pedagogical Sciences of Ukraine, republic Ukraine, city of Kiev,

ORCID ID https://orcid.org/0000-0001-6596-355

E-mail address: Humennyi@ivet.edu.ua 